ГОАР КАРАГЕЗЯН*

Кандидат филологических наук Института литературы им. М. Абегяна НАН РА gkaragyozian@gmail.com

DOI: $10.52853 / 18294073-20213.27-24$

\title{
МУЧЕНИЧЕСТВО СОРОКА ОТРОКОВ СЕБАСТИИ В ЕВРОПЕЙСКОЙ ИСТОРИКО-ГЕОГРАФИЧЕСКОЙ ЛИТЕРАТУРЕ
}

\begin{abstract}
Ключевые слова: Себастия, 40 мучеников Севастии, агиография, легенда, хождения, записки путешественников, сакральный ландшафрт.
\end{abstract}

\section{Вступление}

В четвертую субботу Великого поста Армянская Апостольская церковь отмечает день памяти Сорока святых отроков (воинов-христиан), принявших мученическую смерть за веру во Христа в начале IV века, в Малой Армении, в армянской Севастии (Себасте) ${ }^{1}$. Праздник в память о Сорока мучениках во всех древнейших месяцесловах на Востоке и Западе относится к кругу праздников и дней памяти наиболее чтимых святых². Им посвятили энкомии Василий Великий, Григорий Нисский и Ефрем Сирин. Иоанн Дамаскин и Феофан Никейский написали стихиры на день 40 мучеников, который отмечается греческой и латинской церквями 9 марта. Самый ранний рассказ об их мученичестве изложен Василием Кесарийским в беседе «На святых 40 мучеников» (In sanctos quadraginta martyres). В Севастии, над местом погребения мощей Сорока мучеников, был построен монастырь ${ }^{3}$, который до основания разрушил Тимур 4 .

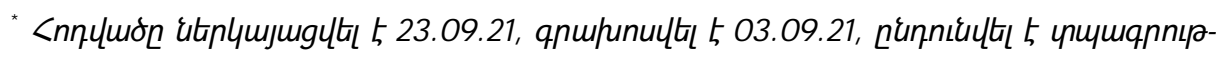
јшй 19.1121:

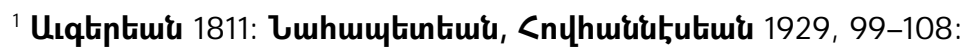

${ }^{2}$ Ростовский 1840, 117.

${ }^{3}$ huth6timu 1806, 286: 
Мученичество Сорока отроков Себастии в европейской...

Почитание Сорока мучеников получило широкое распространение. В их честь было возведено множество церквей: церковь 40 святых отроков в Севастии (IV в.), храм 40 Севастийских мучеников (Ксиропотамский монастырь) на Афоне (V в.), собор 40 мучеников в Алеппо (ок. 1429), церковь 40 мучеников в Тбилиси ( ?), храм 40 Севастийских мучеников (Нокалакеви, Грузия, VI в. ?), монастырь 40 отроков в селе Дсех (Лори, Армения, Х век), в Велико-Тырново (Болгария, 1230), в Слободе (Москва, XVI в.), церковь 40 мучеников в Переславле-Залесском (1628), в Яссах (Румыния, 1760), часовня 40 мучеников на римском Форуме, мартириум 40 мучеников в Бейруте (VI век), колоннада 40 мучеников там же (VI век), мартириум (IV век) с мощами святых на Масляничной горе в Палестине, пещерная часовня 40 Святых (Agioi Saranta) в Протарасе (Kипр, ?), башня 40 мучеников в Рамле (Палестина, ?), церковь 40 мучеников в районе Александретта провинции Хатай (1872), церковь 40 Севастийских отроков в армянском квартале Нор Мараш Бурдж Хаммуда (Ливан, 1929). Албанский город Саранда свое название получил от византийского монастыря Агия-Саранда ('Аүıо $\Sigma \alpha \rho \alpha ́ v \tau \alpha)$, что переводится с греческого языка как «сорок святых». Город был построен в X веке в честь Сорока Великомучеников Севастийских. В годы османского владычества название сменилось на Айя-Саранда (на европейских картах - Санти Кваранта), армянская церковь 40 мучеников (Милан, 1957), армянская церковь 40 мучеников в округе Ориндж (США, 1986).

Место действия мартирии - Севастия - древний город в Каппадокии и Понте (историческая Малая Армения). Именно здесь имели место трагические события, связанные с воинами XII Молниеносного легиона, отказавшимися принести жертву языческим богам и замученными в Севастийском озере. Эта история на протяжении веков притягивала к себе внимание художников, поэтов, писателей, путешественников.

В контексте поставленной проблемы особый интерес представляют памятники европейского раннего средневековья «История фрранков»

${ }^{4}$ Об этом пишет Ованнес Себастаци в «Истории Себастии»: «[Ленг Тимур] до основания снес прекрасный храм Сурб Карасниц /Святой Сороковицы/, с сорока куполами, под которыми были похоронены их тела», Себастаци 2015, 51 
Карагезян Г.

(«Historia francorum») и «Семь книг о чудесах» («Miracula et opera minora») крупнейшего представителя фрранцузской историографии VI века Григория Турского. Франкскому историку принадлежит далеко не последняя роль в деле популяризации мученичества 40 отроков. Так, в «Семи книгах о чудесах», наряду с местными сказаниями, представлены образцы агиографии восточных стран, среди которых ценным для армянской исторической науки является описание мученичества $48^{5}$ армян Севастии, подвергшихся гонениям в период поздней Римской империи, во времена Лициния, в 320-ом году. Ниже приводится отрывок из «Семи книг о чудесах»: «Говорят, что в Армении, на горах, где крайний холод, вызванный их божественной высотой, сковал землю и воду, 48 христиан восприняли мученическую смерть. Творец божественного закона поведал нам о немалой высоте этих гор, сказав, что на их вершине остановился ковчег Ноя. Здесь некий гонитель на христиан велел вырыть в земле глубокий водоем и заполнить его водой. Затем, он приказал оголить людей, привязать их руки к спине и опустить в застывшее от мороза озеро. Неподалеку находилась баня. Тогда он им сказал: «Выбирайте одно из двух! Погибнуть во льдах от холода, исповедуясь вашему Христу, или же, отрекаясь и принося в жертву Бога, искупаться в бане и не умереть так убого за человека, который был распят. Поскольку все отказались продать душу дьяволу, охранник увидел 48 драгоценнейших венцов, падающих с неба и опускающихся на их головы. Один из венцов вознесся обратно в небо, так как один из них изменил вере. Надзиратель, о котором мы уже говорили, видя происходящее, громкогласно объявил себя христианином и произнес: «Я хочу умереть вместе с ними!». Он был предан различным пыткам, с него сняли одежду, но не смогли отнять веру, его опустили в озеро, дабы он страдал вместе с другими, но он обрел венец, потерянный тем презренным. Несчастные умирали от холода, зубы их скрежетали, голоса стихали. И лишь шепот молитвы поднимался из груди к небу, молитвы, которую слышал лишь Господь, проникающий в сердца. Измученные холодом и

5 Число 48, приведенное Турским (в агиографической традиции 40), связано с ассоциацией мучеников Севастии с 48-ью Лионскими мучениками, пострадавшими в годы правления Марка Аврелия. 
Мученичество Сорока отроков Себастии в европейской...

голодом, они надеялись лишь на небо. Однако единственный судья велел в семь раз сильнее растопить баню, чтобы те, которые сопротивлялись холоду, были доведены до отчаяния. Их, исповедующих Христа, вытащили из озера и заставили пройти сквозь обжигающие пары. Однако они мужественно терпели все пытки, дабы заслужить более высокую пальмовую ветвь. Оставив там тела, поручив душу Богу, они мирно завершили свои муки. Тогда гонитель, видя, что побежден их стойкостью и желая испытать торжество по крайней мере после смерти тех, которых не смог укротить при жизни, приказал сжечь их тела и бросить в реку. Когда это было сделано, христиане в слезах узрели новое чудо: волны, сопротивляясь, не поглотили их останки, они их поддерживали на поверхности как нечто святое. Христиане имели счастье их собрать и похоронить с большими почестями (здесь и далее переводы наши - Г.К.)».

Продолжение истории о мучениках Севастии можно найти в «Истории фрранков» Григория Турского - главном источнике по культурной, политической, религиозной истории Франкского государства V-VI веков. Это, пожалуй, первое на Западе обращение к героической странице истории армянского народа - к борьбе армян с зороастрийским Ираном. Франкский историк рассказывает легендарную историю о Вардане Мамиконяне «Красном Вардане» и главарях восстания 572 года против Сасанидской Персии, которые бежали в Византию, ко двору императора Юстина, прося о помощи и поведав о политике преследования армян и религиозных гонениях ${ }^{7}$.

Возникает вопрос: каким образом дошли до епископа из Тура сведения о восстании армян против персидского гнета, приведенные в «Истории фрранков», а также история 48 мучеников в «Семи книгах о чудесах»? Ответ на этот вопрос находим у самого историка: «На шестнадцатом году правления короля Хильдеберта, в город Тур пришел из заморских стран некий епископ по имени Симон. Он нам поведал, как его взяли в плен и угнали из Армении в Персию. Ведь царь персов вторгся в армянские земли, захватил добычу, поджег церковь и этого епископа вместе с его общи-

${ }^{6}$ Gregorii episcopi Turonensis 1969, 102-103.

${ }^{7}$ Турский 1987, 104-105. 
ной увел в плен. Тогда же персы попытались поджечь и базилику Сорокавосьми св. мучеников, о которых я упоминал в книге о чудесах ...Натаскав в базилику дров и облив их смолою, смешанной со свиным жиром, они подкинули туда пылающие факелы; однако все приготовленное для пожара отнюдь не занялось от огня. Так что, увидев "великие дела Божии», они отступили от базилики» ${ }^{8}$.

Приведенный выше отрывок позволяет отчасти уяснить канал проникновения темы севастийских мучеников в литературу путешествий. Благодаря епископу из Тура мученичество 48 отроков (40) вошло в историколитературный обиход многих народов. Могилу святых, подвергавшихся гонениям за приверженность христианству, как правило, посещали ходившие на Восток путешественники. Придерживаясь хронологического порядка, перейдем к рассмотрению записок путешественников, в которых нашла место история 40 отроков и города Севастии.

В 1255-ом году Севастию посетил Гийом де Рубрук. «В Себасте, что в Малой Армении, - пишет Рубрук, - мы были на Страстной неделе. Так посетили мы могилу Сорока мучеников. Там есть церковь во имя святого Власия ${ }^{9}$, но я не мог пойти в нее, так как она находится наверху, в крепости» ${ }^{10}$.

В 1465-1466 гг. через Севастию лежал путь русского купца Василия, которого «сподобил бог видеть и поклониться святым местам». В «Хожении гостя Василия в Малую Азию, Египет и Палестину» (1465-1466 гг.) читаем: «Город Сивас, а по-нашему Севастия, где были замучены сорок мучеников. Внутри этого города озеро и баня, где их мучили. В городе православные и армяне живут, а турок мало. Церкви христианские имеются в городе, за городской стеной ...Когда сорок мучеников замучили в озере, мучители их извлекли. Пьют эту воду люди и никакого вреда не испытывают, но только исцеление черпают» ${ }^{11}$.

\footnotetext{
${ }^{8}$ Турский 1987, 306.

${ }^{9}$ Святой Власий - Власий Себастийский (Saint Blaise).

${ }^{10}$ Путешествие в восточные страны Плано Карпини и Рубрука 1957, 192.

${ }^{11}$ Хожение гостя Василия 1951, 351
} 
Мученичество Сорока отроков Себастии в европейской...

Известный армянский писатель и путешественник Симеон Лехаци, отправившийся в 1608 году из Львова в путешествие - паломничество, описывает в своих «Путевых заметках» памятные места, связанные с Сорока Севастийскими мучениками. «За городом Себастия находились озеро и баня Сорока отроков, впрочем, вода высохла»"

Упоминание о Севастии мы встречаем и в хождении русского купца Василия Гагары, отправившегося в 1634-ом году в Иерусалим. Путь его лежал через Севастию, в рассказе о которой он естественно упомянул о Сорока мучениках и озере, расположенном на расстоянии 15 поприщ от города («Изъ Ерзерума шелъ на Севастію, где мучени беша 40 мученикъ. Да близъ того же города Севастія есть озеро 15 поприщь оть города: и в

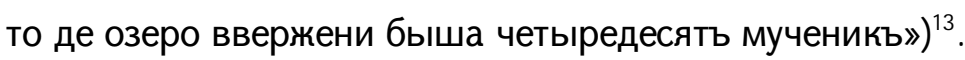

Более пространный рассказ о городе Севастии заключен в «Путешествии антиохийского патриарха Макария ${ }^{14}$ в Россию в половине XVII века», представленный его сыном, архидиаконом Павлом Алеппским». 15-ая книга «Путешествия» содержит информацию по интересующей нас теме: «Этот город - тот самый, который по-гречески называется Севастия; а от этого имени назвали его по-арабски Сивас. В этом именно городе пострадали сорок мучеников. Место, где было озеро, ныне представляет высохшее дно. По-видимому, впоследствии, когда Тамерлан разрушил этот город и его стены, оставив ему теперь только следы былого величия, вода из озера вытекла. что касается места, где были помещены мученики, то это полукруглый свод, наполненный внутри водою, так как вблизи него находятся несколько источников воды, вытекающих из двух различных мест. Эту воду до сих пор называют агиасмой ${ }^{15}$. Нам рассказывали, что ежегодно, утром в день праздника мучеников, из нее появляются две рыбы, как чудесное знамение. Потом провели нас к месту, где были сожжены их святые кости: оно находится за стенами, и на этом месте была боль-

12 Симеон Лехаци 1965, 150.

${ }^{13}$ Списокъ хожденія въ Палестинскихъ местахъ убогаго Васілия, по прозвищу Гогары 1849, 112.

${ }^{14}$ Макарий был сыном православного священника-араба. Возведён в сан патриарха Антиохийского в 1648 году, под именем Макария III.

${ }^{15}$ Агиасма - вода, освященная в храме. 
шая церковь, от которой еще видны обломки колонн и краеугольных камней. В день праздника мучеников христиане приходят со своими священниками, совершают молебен и поют им службу» ${ }^{16}$.

В тексте архидиакона Павла местом казни Сорока отроков является полукруглый свод, наполненный внутри водой. Павел обращается также к вопросу исчезновения Севастийского озера, выдвигая гипотезу, что оно высохло по причине разрушения городских стен в период нашествий Тамерлана. Место захоронения останков мучеников и озеро, в котором они были утоплены, встраиваясь в структуру сакральной топографрии, обретают статус святого места, места паломничества для христиан. На могиле святых стали происходить чудеса, которые также есть проявление божественного вмешательства. Да и вода полукруглого свода на месте захоронения мучеников рассматривалась как нечто священное. «Второй Иордан сошествия Сына Божьего», - так характеризует это место Карапет Габикян, очевидец насильственной депортации армян Севастии в 1915 году.

В 1849-1852 годах Севастию посетил русский генерал Е.И. Чириков, являвшийся членом Международной Комиссии по определению границ между Турцией и Персией. В своем «Путевом журнале» он сделал следующую запись: «Под самыми городскими стенами [Сиваса] - прудик ${ }^{17}$ Сорока мучеников Кесарийских; над этим прудиком витают, по поверью, 40 жаворонков - души святых мучеников. Температура воды в бассейне $5^{\circ}$, при наружной в $10^{\circ} .9$ марта святят эту воду. Затем навестили армянский монастырь Животворного Креста, частицу которого принес сюда апостол Фаддей, построивший один из приделов; другой придел построен был Св. Григорием перед подвигом просвещения Армении. Здесь хранятся мощи апостолов Фаддея и Варфоломея, Св. Николая, Василия и др.» ${ }^{18}$.

Как видим, сакральный ландшафрт продолжает наполняться новыми смыслами. Согласно житию, венцы, появившиеся над головами 40 отроков, впоследствии превратились в жаворонков, которые сочетают в своей

16 Путешествие антиохийского патриарха Макария 1896, 132.

17 Этот прудик описывает и Г. Инджиджян в «Географии четырех частей света». Он

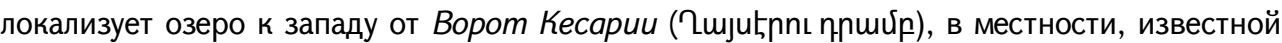
под названием Stinıng, hi6h6tum 1806, 286.

18 Путевой журнал Е.И. Чирикова 1875, 32. 
Мученичество Сорока отроков Себастии в европейской...

символике небесное и хтоническое, божье и богоборческое начала. Праздник наступления весны приурочен у многих народов ко дню памяти Сорока мучеников. В народно-христианской традиции славян день памяти Сорока мучеников назывался Сороки, Жаворонки. Жаворонками также называли выпекавшиеся к празднику мучные изделия в виде птиц или солнца. По другой версии - песня этих птиц напоминает молитву мучеников Севастии. Свидетелем празднования этого праздника греками был фрранцузский путешественник и живописец Гийом-Жозеф Грело, автор «Реляции о новом путешествии в Константинополь», совершенном в 1672-1675-ых гг. Книга иллюстрирована гравюрами, выполненными по рисункам Грело. что касается дня памяти Севастийских мучеников, то он, как отмечает Грело, входит в число четырех наиболее чтимых праздников: дней памяти Св. Андрея, Св. Николая, Св. Георгия и Сорока мучеников ${ }^{19}$. Грело пишет, что праздник 40 мучеников под греческим названием Agii Sarandüs широко празднуется ${ }^{20}$ на островах и в небольших селениях, в Константинополе же разрешается отмечать этот день лишь на площади, за Зеркальным дворцом. Грело недоумевает по поводу празднования святой сороковицы греками, которые испытывали к армянам далеко не самые теплые чувства, хотя именно в их стране эти святые отдали свою жизнь за веру во Христа ${ }^{21}$.

Из Константинополя перенесемся в Палестину, где находилась известная башня Сорока мучеников. Описание этой башни дано в «Путешествии в Левант» нидерландского путешественника и художника Корнелиса де Брюйна, совершенном в 1678-1681 гг: «Недалеко от старого города можно увидеть высокую квадратную башню, похожую на колокольню. Говорят, она была прежде выше и была возведена в честь 40 мучеников, при-

${ }^{19}$ Grelot 1680, 205.

20 Грело отмечает, что празднование дня памяти Сорока мучеников сопровождается пиршеством, танцами и песней, которую он записал на слух: Ascore-psomai kai asinai Dançons et passons en plaisirs (Давайте танцевать и веселиться) Ton agion Sarandons inai Le jour des Quarante Martyrs (В День Сорока мучеников).

${ }^{21}$ Grelot 1680, 205. 
нявших мученическую смерть в Армении» ${ }^{22}$.На одном из своих рисунков де Брюйн запечатлел панораму города Рамла и башню Сорока мучеников.

Двумя десятилетиями раньше в 1665 году каноник аббатства Сен-Дени Жан Дубдан совершил путешествие в Св. Землю. Он посетил в Рамле церковь Сорока мучеников и был свидетелем трехдневного празднования с танцами и песнями дня памяти мучеников Севастии мусульманами, которые были уверены, что эти мученики - «мавры (арабы) по национальности и магометане по вере» ${ }^{23}$.

Архиепископ Парижа Жорж Дарбой, совершивший в XIX веке паломничество в Св. Землю, словно повторяет слова своего предшественника относительно преобразования церкви 40 мучеников в мечеть и «приватизации» мусульманами христианских святых. По дороге из Яфрфы в Рамлу внимание Дарбоя привлекла башня Сорока мучеников, которая, по словам путешественника, некогда была «часовней монастыря, остатки которого еще сохранились; ныне [башня] превращена в минарет мечети, более того, арабы, завладев церковью, присвоили частично действующие здесь церковные традиции. Последователь Корана обращает в благочестивых мусульман христианских героев-мучеников и отправляется в паломничество к башне [40] мучеников равно, как это имело место до него»" ${ }^{24}$.

Английский путешественник Джордж Робинсон, посетивший Рамлу в 1830-1831 гг., отмечает, что башня или минарет 40 мучеников единственная сохранившаяся достопримечательность города, которая «была некогда частью церкви, возведенной в честь 40 мучеников, преданных смерти в Армении, в Себасте. Наверх можно подняться по лестнице, состоящей из 125 ступеней. С вершины башни открывается прекрасный вид на Саронскую долину. Церковь, в комплекс которой некогда входила башня, была обращена султаном Египта Saffr-ed-din-oм ${ }^{25}$ в мечеть» ${ }^{26}$.

\footnotetext{
22 De Bruyn 1714, 251

${ }^{23}$ Doubdan 1666, 469.

${ }^{24}$ Darboy 1852, 74-75.

25 Автор имеет в виду Салах-ад-Дина, захватившего в 1177 году Рамлу.

${ }^{26}$ Robinson 1838,31
} 
Мученичество Сорока отроков Себастии в европейской...

Однако не только церкви, башни и часовни в память о 40 мучениках возводились повсеместно, но и их мощи нашли пристанище во многих странах. Григорий Нисский (ок. 335-394) в первом похвальном слове Святым Сорока мученикам, произнесенном 9 и 10 марта 383-го года в Севастии, в часовне на месте кончины 40 мучеников, объявил, что мощи святых мучеников Севастийских рассеяны по всему свету.

В пятый том «Путешествия через Московию в Персию и Индию» де Брюйна включен отрывок из «Путешествия» Мусо, совершенного около 1668 года. Описывая пригород Salhier, расположенный к северо-западу от старого города-крепости Дамаск, Мусо пишет, что здесь погребены 40 мучеников, и что поодаль можно обнаружить большое озеро ${ }^{27}$.

На место погребения мощей Сорока мучеников претендует и Грузия. Об этом повествует А.Н. Муравьев, посетивший Нокалакеви - город-крепость в западной Грузии. Церковь Сорока мучеников, по описанию Муравьева, «складена частию из дикого камня, частию из кирпича, и, по своим Византийским фрормам, являет глубокую древность. Можно согласиться с мнением ученых путешественников, которые относят ее ко временам Иустиниана, ибо известно по истории Прокопия, что он соорудил церковь у Лазов, когда Царь их обратился в христианство: и так эта церковь может быть VI века и, вероятно, посвящена была Богоматери, как большая часть храмов Иустиниановых. Но здесь она носит название Сорока мучеников, потому что в правом приделе показывают сорок кружков, где будто бы погребены священные останки страдальцев Севастийских. Местное предание называет даже озером Сорока мучеников ту живописную часть реки Техуры, которою мы любовались из подземелья, и утверждает будто бы они пострадали на этом месте». «На чем-нибудь, однако, должно быть основано такое предание», - задается он вопросом. Далее сам же отвечает на им же заданный вопрос: «Если, быть может, императором Иустинианом даны были частицы мощей Св. мучеников, для нового храма, и там положены они, по образцу их погребения в Севастийс-

${ }^{27}$ De Bruyn 1732, 419. 
кой церкви: то не мудрено, что благочестие новообращенных Христиан искало себе усвоить и поприще их страданий» ${ }^{28}$.

\section{Заключение}

Как мы могли убедиться, история Сорока мучеников Севастии имела широкое хождение в Европе и Азии. День их памяти отмечался многими народами. Церкви, монастыри и часовни возводились во многих странах. Частицы мощей святых были рассеяны по всему миру. Агиографическая легенда об армянских святых, «превзошедших других величием природы, - сих ратоборцах Христовых, воинах Святого Духа, защитниках веры, оплотах града Божия» ${ }^{29}$, своим сюжетным накалом производила сильное впечатление на аудиторию и служила примером для подражания, эталоном мужества и верности Христу. Путешественники, посетившие связанные с мучениками Севастии памятные места, непременно включали в свой нарратив историю их мученичества. Их разновременные рассказы выстраивались лесенкой (выражение Д. Замятина) ${ }^{30}$, давая достаточно целостное представление о легенде, ее происхождении, развитии, а также культовых сооружениях, возведенных в их честь на протяжении веков.

\section{БИБЛИОГРАФИЯ}

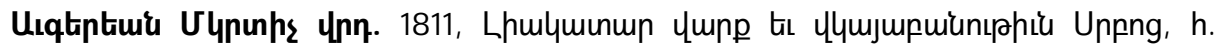
F, Ytühtinhl, unu. U. 2uqump, 568 52:

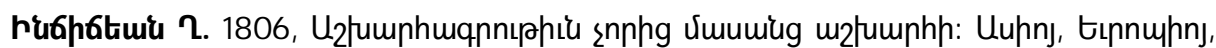

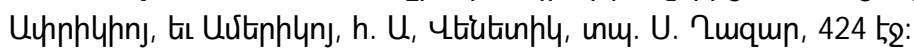

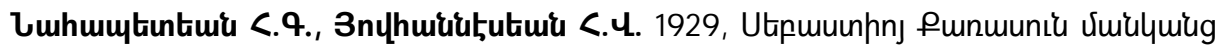

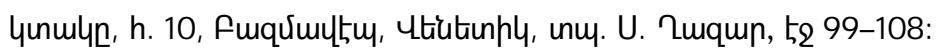

Армянские жития и мученичества V-XVII вв. 1994, перевод с древнеарм. К. ТерДавтян, Ереван, «Наири», 482 с.

Арешян С. 1951, Заметки русских путешественников об Армении (XIV-XVII вв.), Известия АН Арм. ССР, Ереван, N 3, с. 45-52.

Замятин Д. 2002, Образы путешествий, «Социологические исследования»,Москва, № 2, c. 12-22.

${ }^{28}$ Муравьев 1848, 268-269.

${ }^{29}$ Святитель Григорий Нисский, Похвальное слово святым Сорока мученикам (второе).

${ }^{30}$ Замятин 2002, 15. 
Мученичество Сорока отроков Себастии в европейской...

Муравьев А.Н. 1848, Грузия и Армения, ч. III, СПб., 315 с.

Путевой журнал Е.И. Чирикова 1875, Записки Кавказского отдела Императорского Русского географического общества, кн. 9, СПб., Типографрия О.И. Бакста, 49 с.

Путешествие антиохийского патриарха Макария в Россию в половине XVII века, описанное его сыном, архидиаконом Павлом Алеппским, 1896, Москва, 145 с.

Путешествие в восточные страны Плано Карпини и Рубрука 1957, Москва, изд. географической литературы, 270 с.

Ростовский Дм. 1840, Жития святых 1840, 9 Марта, https://azbyka.ru/otechnik/ Dmitrij_Rostovskij/zhitija-svjatykh/225 (10.01.2021).

Святитель Григорий Нисский, Похвальное слово святым Сорока мученикам (второе), https://azbyka.ru/otechnik/GrigorijNisskij/pohvalnoe_slovo_40muchenikam_vtoroe/ (10.01.2021).

Себастаци Ов. 2015, История Себастии, Ереван, «Гитутюн», 202 с.

Симеон Лехаци 1965, Путевые заметки, Москва, «Наука», 317 с.

Списокь хожденія вь Палестинскихь местахь убогаго Васілия, по прозвищу Гогары 1849 (собр. И. Сахаровым), т. 2, СПб., тип. Сахарова, 675 с.

Турский Григорий 1987, История фрранков, Москва, «Наука», 459 с.

Хожение гостя Василия в Малую Азию, Египет и Палестину, 1984, Книга хожений, М., «Советская Россия», 361 c.

Darboy G. 1852, Jérusalem et la Terre-Sainte: notes de voyage. Paris, Belin-Leprieur et Morizot, $399 \mathrm{p}$.

De Bruyn Cornelis 1714, Voyage au Levant, Paris, chez Cavelier, 408 p.

Doubdan Jean 1666, Le voyage de la Terre-Sainte, Paris, Pierre Bien Fait, 715 p.

Gregorii episcopi Turonensis. Miracula et opera minora 1969, Monumenta Germaniae Historica, t.1, Hannoverae, Hahnsche Buchhandlung, 465 p.

Grelot G.J. 306, Relation nouvelle d'un voyage de Constantinople, Paris , Rocolet, 306 p.

Robinson George 1838, Voyage en Palestine et en Syrie, t. 1, Paris, Arthus Bertrand, 422 p.

Voyages de Corneille Le Bruyn par la Moscovie, en Perse, et aux Indes Orientales 1732, t. 5, à la Haye, Neaulme, 1732, 498 p.

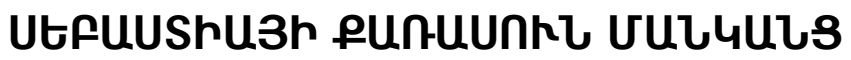

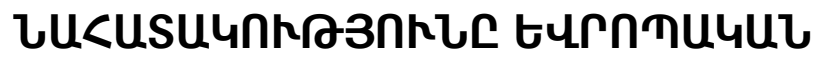

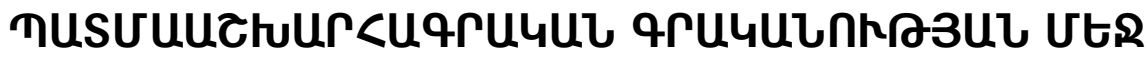

\author{
чUกU१3กR3แน 9.
}

\section{Uরưnunnư}

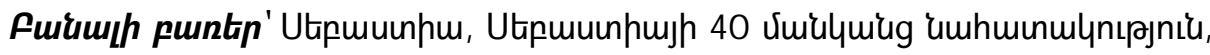

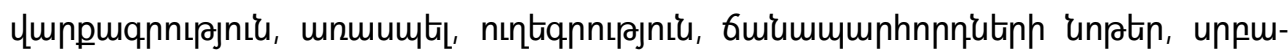
quí hnn: 


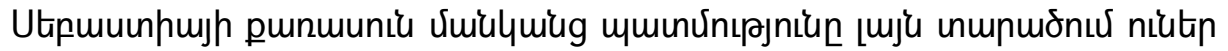

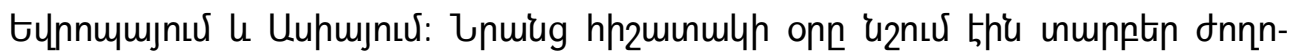

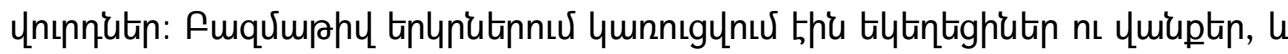

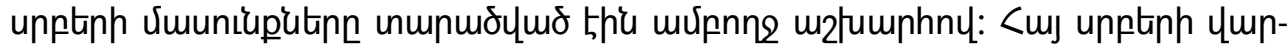

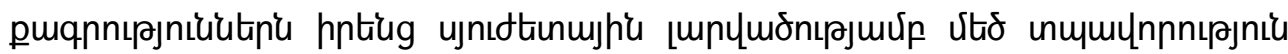

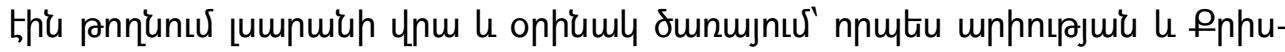

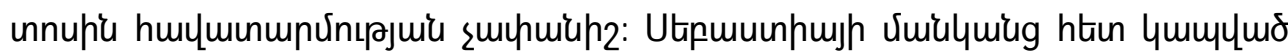

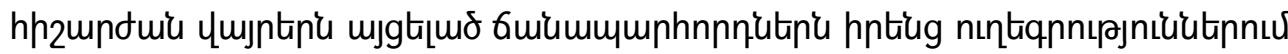

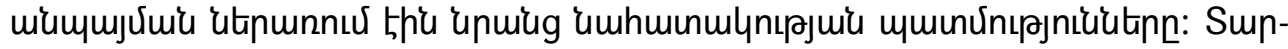

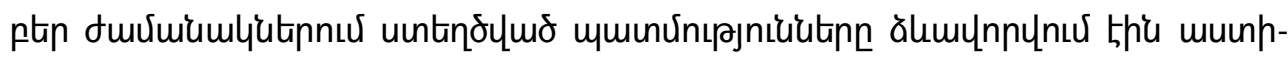

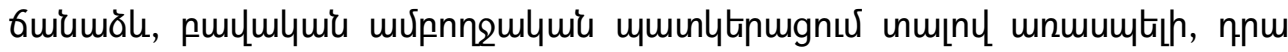

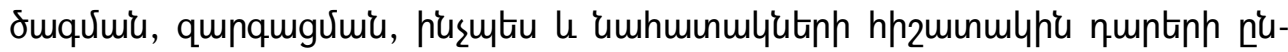

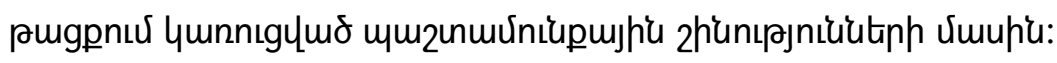

\section{MARTYRDOM OF THE FORTY YOUTHS OF SEBASTIA IN THE EUR OPEAN HISTORICAL AND GEOGRAPHICAL LITERATURE}

\section{KARAGYOZYAN G.}

\section{Summary}

Keywords: Sebastia, forty Martyrs of Sebastia, hagiography, legend, travel writing, sacred land.

The story of the Forty Martyrs of Sebastia was widespread in Europe and Asia. Many nations marked a remembrance day in their honour, and many countries built churches, monasteries, and chapels, commemorating them. The relics of the saints were scattered all over the world. The tension of the plot of the hagiographic legend about the Armenian saints made a strong impression on the audience and served as an example of courage and loyalty to Christ. The travellers, who visited the memorial sites associated with the Sebastian martyrs, included this story of martyrdom in their narratives without fail. The travellers' narrations in different periods, built up like a ladder, introducing quite a holistic idea of the legend, its origin and development, as well as of the religious buildings erected over centuries to honour the memory of martyrs. 